PROBLEMS

OF EDUCATION IN THE $21^{\text {st }}$ CENTURY Vol. 77, No. 5, 2019

598

\section{EXPLORING THE LEADERSHIP SKILLS OF PRE-SERVICE SOCIAL WORK STUDENTS: IMPLICATIONS FOR SOCIAL WORK EDUCATION}

\author{
Nadiia Horishna, Hanna Slozanska, Olha Soroka \\ Ternopil Volodymyr Hnatyuk National Pedagogical University, Ukraine \\ E-mail: nadiahorishna@yahoo.com, kulynyak@elr.tnpu.edu.ua, \\ sorokaolga175@gmail.com \\ Lyudmila Romanovska \\ Khmelnitsky National University, Ukraine \\ E-mail: Iroman@online.ua
}

\begin{abstract}
The importance of leadership is discussed widely in the social work literature. However, little is known about the leadership skills of social work students and factors affecting their development in the environment specific to higher educational institutions (HEIs). This research aimed to find out what skills pre-service social work students had related to leadership and to determine if significant differences existed in terms of such predictor variables as level and form of study, employment status, and involvement in co-curricular activities. The research employed the quantitative approach based on a descriptive cross-sectional survey involving a sample of 158 social work students from three Ukrainian universities. The research group consisted of $88 \%$ female and $12 \%$ male respondents, aged between 19 and 31. Data were obtained through the Student Leadership Outcomes Inventory, which contained 60 items measuring skills on 8 scales: (a) self-management, (b) interpersonal communication, (c) problem-solving and decision-making, (e) cognitive development and critical analysis, (f) organization and planning, ( $g$ ) self-confidence, (h) diversity awareness, and (h) technology which served as outcome variables. All items were rated along a 5-point Likert scale, from poor (1) to excellent (5). The results of the research revealed lower than average levels of leadership skills and existing significant differences by outcome variables for the sample population. The findings suggest the need to strengthen the leadership skills of social work students through the implementation of formal and informal developmental activities and recognition of leadership participation within the social work curriculum.
\end{abstract}

Keywords: descriptive cross-sectional survey, leadership development, leadership skills, pre-service social work students, social work.

\title{
Introduction
}

Leadership is considered to be an essential component of any profession. Social work is not an exception. The crucial role of leadership is captured in its revised definition. Social work is a practice-based profession and an academic discipline that promotes social change and development, social cohesion, and the empowerment and liberation of people. Principles of social justice, human rights, collective responsibility and respect for diversities are central to social work (International Federation of Social Workers, 2014). The need for leadership in social work becomes stronger as the macro forces affecting social work practice, including globalization, migration, diversity, demographic aging, increasing income inequality between the rich and the poor, become more obvious. 
The challenges faced by the profession and the values that it adheres to, by definition, not only require leadership on social workers' part, but also define leadership. As Nandan, London, and Bent-Goodley (2015) have noted, social workers are called upon to lead and facilitate social change that can have a lasting impact on communities and people. Grint (2010) has argued that social workers must be leaders at all levels as it belongs to their role to deal in wicked problems. They must envision a desirable future, innovate and facilitate innovation, promote supportive values and intelligent strategies.

In Ukraine, the need for social workers' leadership, given the short history of social work as a profession, is even more pronounced. Having been introduced to Ukraine in 1991 after the Soviet Union collapse, social work continues to play a crucial role in addressing a number of social problems, such as internal refugee crisis, poverty, unemployment, human rights violation, inadequate housing, child or spousal abuse, substance abuse, etc. (Horishna \& Slozanska, 2017, p. 165). Currently, the profession is in the process of a fundamental shift from the state to the local level of social services delivery. Institutionalization of practical social work on the local level takes place under the reform of decentralization of authority (Slozanska, 2017, p. 293). Consequently, an increasing number of social workers are being employed by the amalgamated territorial communities. They are expected to create new social service agencies and to organize, administer, plan and provide a broad array of new community-based services, such as child protective services, in-home, day and palliative care to vulnerable populations. Changes in social services delivery cause the need for more social workers in leadership positions to strengthen capacity-building and to increase the efficiency of local social service agencies, but not only social workers at high-rank positions need leadership skills. No matter where they are in a hierarchy and in what settings they work, they are expected to provide services that are guided by social work values and ethics and address individual and community needs (McDonald \& Chenoweth, 2009). To this end, they must possess a wide repertoire of knowledge and skills with leadership being among them.

Perception and understanding of leadership in social work continuously change and evolve as the role of the profession changes and becomes more complex. There are, therefore, many definitions of social work leadership. Kirst-Ashman (2000, p. 71) defined it as "the act of exerting influence on other group members to direct their behavior, activities, attitudes, or interaction." Skidmore (1990, p. 120) described leadership as a responsibility to guide and control and the ability to influence others to follow the leader. Rank and Hutchinson (2000, p. 499) proposed the following definition: "leadership is a process of advocacy and planning whereby an individual practices ethical and humanistic behavior to motivate others (clients and colleagues) to achieve common goals articulated by a shared vision. Its role has been interpreted as positioning the profession in a more positive and productive capacity (Rank \& Hutchinson, 2000, p. 488), communicating its vision, and creating proactive processes that empower individuals, families, groups, organizations, and communities (Rank \& Hutchinson, 2000, p. 499). In research by these authors, the vision of leadership in social work by the holders of the vision of the profession has been presented. The executives of the National Association of Social Workers (NASW) and the Council on Social Work Education (CSWE) have identified the following five descriptors of social work leadership: (1) proaction which was described as ability to organize, facilitate change, motivate, take risks, innovate; (2) values and ethics were consistent with those, incorporated in the profession's Code of Ethics; (3) empowerment was understood as "instilling hope, confidence, and accomplishment, collaboration, influences, and the ability to identify issues and concerns for policy makers"; (4) vision was elaborated as ability to envision future possibilities and developments, lead the way, set goals and objectives, lead others to achieve them; and (5) communication which was defined as ability to interpret the mission of social work profession to others (Rank \& Hutchison, 2000, pp. 492-493). Rank and Hutchison have also identified six skills necessary for accomplishing leadership goals (Table 1), 
Nadiia HORISHNA, Hanna SLOZANSKA, Olha SOROKA, Lyudmila ROMANOVSKA. Exploring the leadership skills of pre-service social work students: Implications for social work education

PROBLEMS

OF EDUCATION

IN THE $21^{\text {st }}$ CENTURY

Vol. 77, No. 5, 2019

600

but later their uniqueness as pertaining to social work only was questioned by Lawler (2005). Other attempts have been made to identify the leadership skills of social workers in the health care (Globerman, White, Mullings, \& Davies, 2003; Rosenberg \& Weissman, 1995) and the non-profit sectors (Menefee, 1997). However, those endeavors have not been further developed. Comparative data based on the researchers' analysis of leadership skills are presented in Table 1.

Table 1. Skills associated with leadership in social work by different researchers.

\begin{tabular}{|c|c|}
\hline $\begin{array}{l}\text { Rosenberg \& Weissman } \\
\text { (1995) }\end{array}$ & $\begin{array}{l}\text { accurate assessment of environment. } \\
\text { restructuring of an organization. } \\
\text { maintaining one's strengths. } \\
\text { innovation and creativity. } \\
\text { building community partnerships. }\end{array}$ \\
\hline Menefee (1997) & $\begin{array}{l}\text { identify and review the mission. } \\
\text { promote the highest level of professionalism. } \\
\text { assess and plan for the future. } \\
\text { manage internal structures and operations in response to external demands and } \\
\text { operations. } \\
\text { influence both the internal and the external environment to promote the goals and } \\
\text { objectives of the organization. } \\
\text { preserve the legitimacy of agencies' services by means of public relations, } \\
\text { networking, collaboration, and advocacy. }\end{array}$ \\
\hline Rank \& Hutchison (2000) & $\begin{array}{l}\text { communication and interpersonal skills. } \\
\text { ethical reasoning. } \\
\text { community development. } \\
\text { risk-taking. } \\
\text { political. } \\
\text { diversity skills. }\end{array}$ \\
\hline $\begin{array}{l}\text { Globerman, White, Mullings, } \\
\text { \& Davies (2003) }\end{array}$ & $\begin{array}{l}\text { negotiation and facilitation. } \\
\text { collaboration. } \\
\text { regaining power. } \\
\text { innovation, creativity, and flexibility. } \\
\text { specialization. } \\
\text { proactivity. }\end{array}$ \\
\hline
\end{tabular}

Furthermore, some researchers (Jones \& Phillips, 2016; Peters, 2017; Rank \& Hutchinson, 2000) expressed a lot of concern over the lack of leadership skills that impacted the ability of social workers to effectively do their jobs, impeded the profession's ability to advocate for clients' rights and social justice issues, affected the integrity of the social work profession. Yet little empirical attention has been given to the leadership education of social workers. A few studies discussed models and styles used within social work leadership within academic settings (Call, Owens, \& Vincent, 2013; Randle, 2016), the impact of a taught course on the social change model of leadership (Iachini, Cross, \& Freedman, 2015) and students' professional identity (Fronek, Fowler, \& Clark, 2011). Social work researchers noted the lack of leadership curriculum both at undergraduate and postgraduate levels (Knee \& Folsom, 2012) and leadership training for practicing social workers (Austin, Regan, Samples, Schwartz, \& Carnochan, 2011), especially those in general practice, as the reasons for the conspicuous scarcity of social workers in senior administrative positions_(Austin \& Ezell, 2004; Knee \& Folsom, 2012). 
Nadiia HORISHNA, Hanna SLOZANSKA, Olha SOROKA, Lyudmila ROMANOVSKA. Exploring the leadership skills of pre-service social work students: Implications for social work education

The paucity of leadership training in social work education has been acknowledged as the main reason for the leadership gap in the profession (Brilliant, 1986). This situation was due to the decrease in popularity in the latter half of the $20^{\text {th }}$-century macro practice and leadership training in social work in favor of clinical and direct service training (Thompson, Menefee, \& Marley, 1999, p. 115). Leadership did not have a clear focus in undergraduate or graduate social work curricula, despite the recognition of its importance. As a result, the role of leadership in the development of social work's profile in the public eye was absent and would continue to be so if there is no leadership development in the social work training syllabus (Lawler, 2005, p. 129). Strong leadership focus in social work education has been recommended (VidekaSherman, Allen-Meares, Yegidis, \& Yu, 1995).

\section{Problem of Research}

The aforementioned studies have provided useful insight into the leadership within social work practice and education, though they weren't based in Ukraine. Their value was greater considering the lack of research by Ukrainian scholars on leadership training in social work programs. The problem of research is that little is known about how well pre-service social work students are prepared to provide leadership within the profession.

\section{Research Focus}

The purpose of this research was to examine the leadership skills of social work students and to find factors that influence their development. Specifically, it was planned to answer the following research questions:

1. What are the leadership skills of pre-service social work students?

2. Are there differences in leadership skills between undergraduate and graduate students?

3. Are there differences in their leadership skills by the form of study?

4. Are there differences in leadership skills of pre-service social work students upon their employment status?

5. Are there differences in leadership skills of pre-service social work students upon their participation in co-curricular activities?

\section{Research Methodology}

\section{General Background}

The research was performed at three public universities, located in Western Ukraine: Ternopil V. Hnatiuk National Pedagogical University (TNPU), Lviv Polytechnic National University (LNPU), Khmelnytskyi National University (KhNU). They all offered both bachelor's and master's degree programs in social work. Even though they belong to different types of educational institutions, respectively, pedagogical, technical and classical, their curricula had much in common, especially at the undergraduate level. It can be explained by two reasons. First, social workers at the first level of higher education are usually trained as generalist practitioners, capable to work with individuals, groups, and communities and respond to a broad range of social needs and problems. Second, during several past years, the Ministry of Education and Science of Ukraine has taken steps towards the unification of education through the implementation of Standards of Education at all levels for various specialties, including social work. It should be noted that the approved standards do not provide for the formation of leadership competence, although some of its components, such as interpersonal skills, critical thinking, problem-solving, self and organizational management are mentioned there.

\begin{tabular}{l} 
PROBLEMS \\
OF EDUCATION \\
IN THE 21 $1^{\text {st }}$ CENTURY \\
Vol. 77, No. 5, 2019 \\
\hline 601
\end{tabular} 
Nadiia HORISHNA, Hanna SLOZANSKA, Olha SOROKA, Lyudmila ROMANOVSKA. Exploring the leadership skills of pre-service social work students: Implications for social work education

PROBLEMS

OF EDUCATION

IN THE $21^{\text {st }}$ CENTURY

Vol. 77 , No. 5, 2019

The curricula analysis revealed that at bachelor's level all programs had much in similar, including courses in liberal arts, social sciences, generalist social work practice and field instruction (Ternopil V. Hnatiuk National Pedagogical University, 2015; Khmelnytskyi National University, 2015; Lviv Polytechnic National University, 2015). There tended to be slightly larger differences between the programs at the master's level of study due to the programs' peculiarities. The program in KhNU (Khmelnytskyi National University, 2018) prepared students for advanced generalist social work practice. The one in TNPU (Ternopil V. Hnatiuk National Pedagogical University, 2018) had strong focus on social administration in communities, while the program in LPNU (Lviv Polytechnic National University, 2018) provided the opportunity to complete one of two concentrations: social administration or social technologies. Despite some differences, the curricula related to leadership had much in common (Table 2). In none of the universities, courses aimed specifically at leadership development were taught either on bachelor's or master's levels. There also were no informal leadership programs for students developed and introduced on campuses at the time of the research.

Table 2. Courses pertaining to leadership development.

\begin{tabular}{llll}
\hline HEI & TNPU & KhNU & LNPU \\
\hline Area of concentration & $\begin{array}{l}\text { Social administration in } \\
\text { community }\end{array}$ & $\begin{array}{l}\text { Advanced generalist social } \\
\text { work practice }\end{array}$ & $\begin{array}{l}\text { Social administration / Social } \\
\text { technologies }\end{array}$ \\
\hline Compulsory courses & $\begin{array}{l}\text { Social administration and } \\
\text { supervision }\end{array}$ & $\begin{array}{l}\text { Expertise in social work } \\
\text { practice }\end{array}$ & $\begin{array}{l}\text { Expertise in social work } \\
\text { practice }\end{array}$ \\
\hline & Time-management & Staff management & Social work management \\
\hline & Innovations in social work & Innovations in social work & Multicultural social work \\
\hline & Monitoring and evaluation in & Project management & Social work supervision \\
\hline Social work & Internship & Internship & Internship \\
\hline Electives & Wulticultural social work & $\begin{array}{l}\text { Workplace conflict resolution } \\
\text { / Public relations in social } \\
\text { work }\end{array}$ \\
\hline
\end{tabular}

\section{Sample}

A descriptive cross-sectional survey was conducted on a sample of social work undergraduate and graduate students from TNPU $(n=54), \mathrm{KhNU}(n=57)$ and LPNU $(n=47)$ during the second semester of academic year 2018/2019. The survey used a convenience nonprobability sampling technique based on the availability of respondents.

The research sample consisted of $139(88 \%)$ females and $19(12 \%)$ males, a distribution that reflects the gender patterns within the social work profession both in Ukraine (Vasylenko, 2016) and abroad (Pivoriene \& Bardauskiene, 2016). The lower number of employed students $25(15.8 \%)$ in comparison with unemployed $133(84.2 \%)$, on the one hand, is typical for Ukrainian students who prefer not to combine study and work (Fajchuk, 2017; Zherobkina, Kudelya, Samohin, Stadnij, \& Kogut, 2016) and, on the other hand, reflects the situation with the shortage of social work positions. There were no significant differences in the size of students' groups differentiated based on the other variables (Table 3). 
Nadiia HORISHNA, Hanna SLOZANSKA, Olha SOROKA, Lyudmila ROMANOVSKA. Exploring the leadership skills of pre-service social work students: Implications for social work education

Table 3. Sample demographics.

\begin{tabular}{|c|c|c|c|}
\hline \multicolumn{2}{|c|}{ Variable } & \multirow{2}{*}{$\begin{array}{c}\text { Frequency } \\
54\end{array}$} & \multirow{2}{*}{$\begin{array}{c}\text { Percent } \\
34.2\end{array}$} \\
\hline $\mathrm{HEI}$ & TNPU & & \\
\hline & KhNU & 57 & 36.1 \\
\hline & LNPU & 47 & 29.7 \\
\hline \multirow{2}{*}{ Age } & $19-20$ & 110 & 69.6 \\
\hline & $\leq 21$ & 48 & 30.4 \\
\hline Gender & $\begin{array}{l}\mathrm{F} \\
\mathrm{M}\end{array}$ & $\begin{array}{c}139 \\
19 \\
\end{array}$ & $\begin{array}{l}88.0 \\
12.0 \\
\end{array}$ \\
\hline \multirow{2}{*}{ Level of education } & Bachelor & 74 & 46.8 \\
\hline & Master & 84 & 53.2 \\
\hline \multirow{2}{*}{ Form of study } & Full-time & 71 & 44.9 \\
\hline & Part-time & 87 & 55.1 \\
\hline \multirow{2}{*}{ Employment status } & Employed & 25 & 15.8 \\
\hline & Not employed & 133 & 84.2 \\
\hline \multirow{2}{*}{$\begin{array}{l}\text { Involvement in co-curricular } \\
\text { activities }\end{array}$} & Involved & 69 & 43.7 \\
\hline & Not involved & 89 & 56.3 \\
\hline
\end{tabular}

\section{Instrument and Procedures}

Since no tools to measure the leadership skills from social work perspective are available as of yet, in this research, the Student Leadership Outcomes Inventory (the SLOI) was employed to test the students' leadership skills which they developed as a result of their experiences in the social work program. The SLOI, a 60-item measure devised by M. Vann (2000), has been used in many studies within the last two decades and its reliability (using Cronbach's alpha), has been reported by different studies to range between .80 and .94 (Bento \& Ribeiro, 2010; Overocker, 2014) supporting the contention that it is a reliable instrument.

The questionnaire was translated into Ukrainian language and approved by an expert. The Ukrainian version of the SLOI was tested with a sample of 20 students different than that of the study but withdrawn from the same population. The internal consistency of the SLOI measured with the Cronbach's alpha coefficient exceeded the recommended criterion of .700 for all scales.

Eight scales of the SLOI measured skills in (a) self-management, (b) interpersonal communication, (c) problem-solving and decision-making, (d) cognitive development and critical analysis, (e) organization and planning, (f) self-confidence, (g) diversity awareness, and (h) technology. Each scale asked participants to evaluate their leadership skills using a 5-point Likert scale where 1 represented "Poor", 2 - "Fair", 3 - "Good", 4 - "Very good", 5 "Excellent".

Along with the SLOI the sociodemographic questionnaire was developed to collect data in two areas. Information on students' characteristics such as age and gender was gathered to 
Nadiia HORISHNA, Hanna SLOZANSKA, Olha SOROKA, Lyudmila ROMANOVSKA. Exploring the leadership skills of pre-service social work students: Implications for social work education

PROBLEMS

OF EDUCATION IN THE $21^{\text {st }}$ CENTURY Vol. 77, No. 5, 2019

604

ensure the sample was representative of the population. Data on their status as a student and performance (institution, the degree to be obtained, employment status, involvement in specific types of co-curricular activities) served as the variables for this research. Both instruments contained no personal identifiers to maintain respondents' anonymity; each respondent was assigned a unique study identification.

The predictor variables in this research were level of study, the form of study, employment, and participation in co-curricular activities. The item related to employment had two response options: "employed" implied any employment in the field of social work or other related fields either full-time or part-time; "not employed" related to persons who didn't have a job or had the jobs that didn't require a degree or experience. Participation in co-curricular activities entailed involvement in at least one of the followings: academic activities (conferences, publications, soft skills training courses, professional events), volunteering, membership in students' organizations for one year or more. The outcome variables were the students' perception of their skills under the survey headings: (a) self-management, (b) interpersonal communication, (c) problem-solving and decision-making, (d) cognitive development and critical analysis, (e) organization and planning, (f) self-confidence, (g) diversity awareness, and (h) technology.

The research was approved by the ethics committees at the participating universities and oral informed consent was received from students. They were explained the aim and procedures of the study to decide if they would like to take part in it. The students were informed that their participation in the study and responses would not influence their grades. After their verbal agreement, both questionnaires were administered to the students at regular class periods after securing the permission of instructors.

The students received written instructions to be followed in responding to the items. They weren't limited in time to answer the questions; it took approximately 25 minutes to complete. The forms were collected during the same class periods.

168 students completed the questionnaire with a response rate of $94 \%(n=158)$. The final sample comprised of 139 females and 19 males. The average age of the analyzed group was 20.1 years (min.19, max. 31, SD: 1.38, Median: 20). Detailed information on sociodemographic variables is presented in Table 3.

\section{Data Analysis}

First, the data were coded. Second, Cronbach's Alpha Reliability Test was employed to check the reliability of the scales (Cronbach's alpha scores for each SLOI item are provided in Table 4).

A response to the first research question, regarding the leadership skills of social work students, was generated by computing descriptive statistics in each of the eight scales of the SLOI, including median and interquartile range.

Mann-Whitney $U$ test was applied to determine if there was a significant difference in leadership skills between students' groups separated based on predictor variables (second, third, fourth, and fifth research questions). The decision to apply a non-parametric test was taken on the basis that the preliminary tests for normality (the Kolmogorov-Smirnov test) and equality of variances (the Levene's test) demonstrated that the assumptions for normal distribution were not met while the homogeneity of variances was not significant. The significance level in all statistical tests was set at .05. Data were analyzed using SPSS (release 22). 
Nadiia HORISHNA, Hanna SLOZANSKA, Olha SOROKA, Lyudmila ROMANOVSKA. Exploring the leadership skills of pre-service social work students: Implications for social work education

\section{Research Results}

The first research question aimed to identify the leadership skills of social work students. The results presented in Table 4 demonstrate that the participants score highest on the Problemsolving $(M d=2.30, I Q R=2.50-2.00)$ and the Interpersonal skills $(M d=2.30, I Q R=2.50-2.00)$ scales. The lowest scores are on the Self-confidence $(M d=2.05, I Q R=2.30-1.90)$ followed by the Diversity awareness $(M d=2.00, I Q R=2.30-1.80)$ scale.

Table 4. Descriptive statistics for leadership skills of social work students.

\begin{tabular}{|c|c|c|c|c|c|c|c|c|c|}
\hline \multicolumn{10}{|c|}{ Statistics } \\
\hline & & 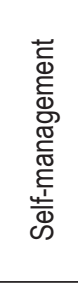 & 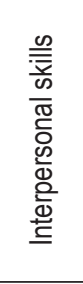 & 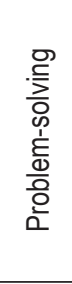 & 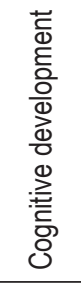 & 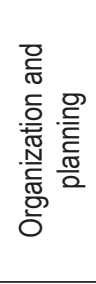 & 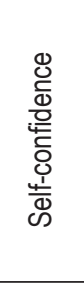 & 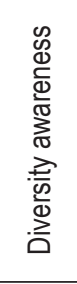 & 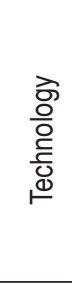 \\
\hline \multirow{2}{*}{$N$} & Valid & 158 & 158 & 158 & 158 & 158 & 158 & 158 & 158 \\
\hline & Missing & 0 & 0 & 0 & 0 & 0 & 0 & 0 & 0 \\
\hline \multirow[t]{2}{*}{ Median } & & 2.10 & 2.30 & 2.30 & 2.10 & 2.10 & 2.05 & 2.00 & 2.20 \\
\hline & 25 & 1.90 & 2.00 & 2.00 & 2.00 & 1.90 & 1.90 & 1.80 & 2.00 \\
\hline \multirow[t]{2}{*}{ Percentiles } & 50 & 2.10 & 2.30 & 2.30 & 2.10 & 2.10 & 2.05 & 2.00 & 2.20 \\
\hline & 75 & 2.30 & 2.50 & 2.50 & 2.30 & 2.30 & 2.30 & 2.30 & 2.40 \\
\hline Cronbach's a & & .77 & .82 & .78 & .76 & .74 & .88 & .77 & .79 \\
\hline
\end{tabular}

The second research question was designed to determine whether the differences in leadership skills exist between undergraduate and graduate students. The results show that graduate students have higher levels of leadership skills on all scales (Table 5). The differences turned out to be significant $(p<.05)$ for all the scales in the questionnaire except for the Diversity awareness $(p>.545)$, which were rated as lowest by the respondents (Table 4$)$. 
Nadiia HORISHNA, Hanna SLOZANSKA, Olha SOROKA, Lyudmila ROMANOVSKA. Exploring the leadership skills of pre-service social work students: Implications for social work education

PROBLEMS

OF EDUCATION IN THE $21^{\text {st }}$ CENTURY Vol. 77, No. 5, 2019

Table 5. Summary of Mann-Whitney U-test for differences in leadership of social work students by level of education.

\begin{tabular}{lllll}
\hline \multicolumn{4}{c}{ Ranks } \\
\hline \multirow{2}{*}{ Self-management } & Level of education $N$ & Mean Rank & $\begin{array}{c}\text { Sum of } \\
\text { Ranks }\end{array}$ \\
\hline \multirow{2}{*}{ Interpersonal skills } & Bachelor & 74 & 65.09 & 4817.00 \\
\cline { 2 - 5 } & Master & 84 & 92.19 & 7744.00 \\
\hline \multirow{2}{*}{ Problem-solving } & Bachelor & 74 & 67.57 & 5000.00 \\
\cline { 2 - 5 } & Master & 84 & 90.01 & 7561.00 \\
\hline \multirow{2}{*}{ Cognitive development } & Bachelor & 74 & 66.91 & 4951.50 \\
\cline { 2 - 5 } & Master & 84 & 90.59 & 7609.50 \\
\hline \multirow{2}{*}{ Organization and planning } & Bachelor & 74 & 59.98 & 4438.50 \\
\cline { 2 - 5 } & Master & 84 & 96.70 & 8122.50 \\
\hline \multirow{2}{*}{ Self-confidence } & Bachelor & 74 & 57.15 & 4229.00 \\
\hline & Master & 84 & 99.19 & 8332.00 \\
\hline Diversity awareness & Bachelor & 74 & 58.31 & 4315.00 \\
\cline { 2 - 5 } & Master & 84 & 98.17 & 8246.00 \\
\hline \multirow{2}{*}{ Technology } & Bachelor & 74 & 77.20 & 5713.00 \\
\cline { 2 - 5 } & Master & 84 & 81.52 & 6848.00 \\
\hline & Bachelor & 74 & 58.89 & 4357.50 \\
\cline { 2 - 5 } & Master & 84 & 97.66 & 8203.50 \\
\hline
\end{tabular}

Test Statistics ${ }^{\mathrm{a}}$

\begin{tabular}{|c|c|c|c|c|c|c|c|c|}
\hline & 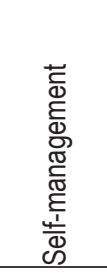 & 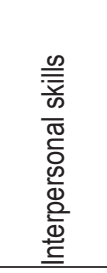 & 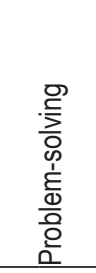 & 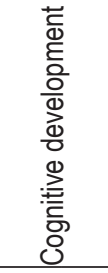 & 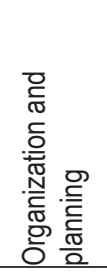 & 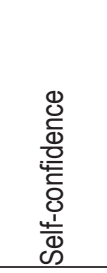 & 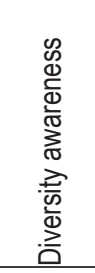 & 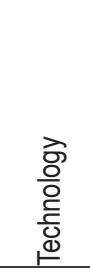 \\
\hline Mann-Whitney U & 2042.0 & 2225.0 & 2176.5 & 1663.5 & 1454.0 & 1540.0 & 2938.0 & 1582.5 \\
\hline Wilcoxon W & 4817.0 & 5000.0 & 4951.5 & 4438.5 & 4229.0 & 4315.0 & 5713.0 & 4357.5 \\
\hline Z & -3.736 & -3.095 & -3.266 & -5.091 & -5.818 & -5.526 & -.605 & -5.344 \\
\hline $\begin{array}{l}\text { Asymp. Sig. } \\
\text { (2-tailed) }\end{array}$ & .0001 & .002 & .001 & .0001 & .0001 & .0001 & .545 & .0001 \\
\hline
\end{tabular}

a. Grouping Variable: Level of education

The third question asked if there were any differences in students' leadership skills by the form of study. The findings indicate that there was no statistically significant difference between full-time and part-time students only in Self-management $(p=.108)$, Interpersonal $(p=.898)$, and Problem-solving skills $(p=.305)$. Differences found on other scales were significant $(p<$ $.05)$ (Table 6). 
Nadiia HORISHNA, Hanna SLOZANSKA, Olha SOROKA, Lyudmila ROMANOVSKA. Exploring the leadership skills of pre-service social work students: Implications for social work education

PROBLEMS

OF EDUCATION

IN THE $21^{\text {st }}$ CENTURY

Vol. 77, No. 5, 2019

Table 6. Summary of Mann-Whitney $U$-test for differences in leadership of social work students by the form of study.

\begin{tabular}{|c|c|c|c|c|}
\hline \multicolumn{5}{|c|}{ Ranks } \\
\hline & Form of study & $N$ & Mean Rank & Sum of Ranks \\
\hline \multirow{2}{*}{ Self-management } & Full-time & 71 & 85.94 & 6102.00 \\
\hline & Part-time & 87 & 74.24 & 6459.00 \\
\hline \multirow{2}{*}{ Interpersonal skills } & Full-time & 71 & 80.01 & 5681.00 \\
\hline & Part-time & 87 & 79.08 & 6880.00 \\
\hline \multirow{2}{*}{ Problem-solving } & Full-time & 71 & 83.61 & 5936.00 \\
\hline & Part-time & 87 & 76.15 & 6625.00 \\
\hline \multirow{2}{*}{ Cognitive development } & Full-time & 71 & 99.35 & 7053.50 \\
\hline & Part-time & 87 & 63.30 & 5507.50 \\
\hline \multirow{2}{*}{ Organization and planning } & Full-time & 71 & 96.50 & 6851.50 \\
\hline & Part-time & 87 & 65.63 & 5709.50 \\
\hline \multirow{2}{*}{ Self-confidence } & Full-time & 71 & 97.89 & 6950.00 \\
\hline & Part-time & 87 & 64.49 & 5611.00 \\
\hline \multirow{2}{*}{ Diversity awareness } & Full-time & 71 & 87.46 & 6209.50 \\
\hline & Part-time & 87 & 73.01 & 6351.50 \\
\hline \multirow{2}{*}{ Technology } & Full-time & 71 & 96.59 & 6858.00 \\
\hline & Part-time & 87 & 65.55 & 5703.00 \\
\hline
\end{tabular}

Test Statistics ${ }^{\mathrm{a}}$

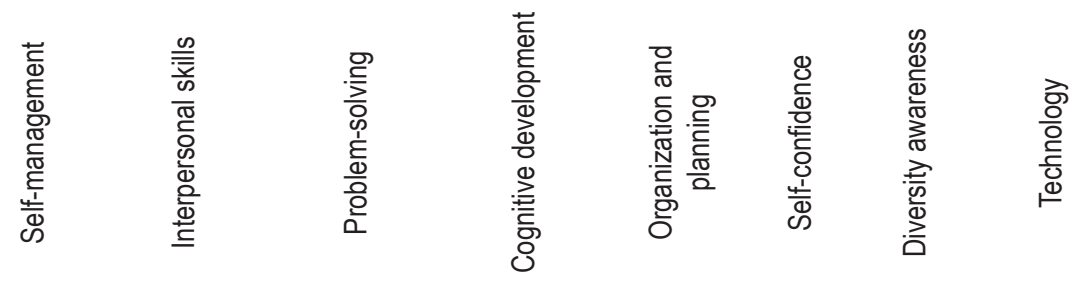

\begin{tabular}{lcccccccc}
\hline $\begin{array}{l}\text { Mann- } \\
\text { Whitney U }\end{array}$ & 2631.0 & 3052.0 & 2797.0 & 1679.5 & 1881.5 & 1783.0 & 2523.5 & 1875.0 \\
\hline Wilcoxon W & 6459.0 & 6880.0 & 6625.0 & 5507.5 & 5709.5 & 5611.0 & 6351.5 & 5703.0 \\
\hline Z & -1.609 & -.128 & -1.025 & -4.982 & -4.259 & -4.615 & -2.018 & -4.264 \\
\hline $\begin{array}{l}\text { Asymp. Sig. } \\
\text { (2-tailed) }\end{array}$ & .108 & .898 & .305 & .0001 & .0001 & .0001 & .044 & .0001 \\
\hline
\end{tabular}

a. Grouping Variable: Form of study

The fourth research question asked if there were differences in leadership skills of social work students upon their employment status. Employed students score higher on all the eight scales of the SLOI. The $p$-value of the Mann Whitney $U$ test lower than .05 indicate that such differences were statistically significant (Table 7). 
Nadiia HORISHNA, Hanna SLOZANSKA, Olha SOROKA, Lyudmila ROMANOVSKA. Exploring the leadership skills of pre-service social work students: Implications for social work education

PROBLEMS

OF EDUCATION IN THE $21^{\text {st }}$ CENTURY Vol. 77, No. 5, 2019

Table 7. Summary of Mann-Whitney $U$-test for differences in leadership of social work students by employment status.

\begin{tabular}{|c|c|c|c|c|c|c|c|c|}
\hline \multicolumn{9}{|c|}{ Ranks } \\
\hline & & \multicolumn{2}{|c|}{ Employment status } & $N$ & Mean Rank & Sum of Ranks & & \\
\hline \multirow{2}{*}{\multicolumn{2}{|c|}{ Self-management }} & \multicolumn{2}{|c|}{ Employed } & 25 & 124.38 & 3109.50 & & \\
\hline & & \multicolumn{2}{|c|}{ Not employed } & 133 & 71.06 & 9451.50 & & \\
\hline \multirow{2}{*}{\multicolumn{2}{|c|}{ Interpersonal skills }} & \multicolumn{2}{|c|}{ Employed } & 25 & 109.32 & 2733.00 & & \\
\hline & & \multicolumn{2}{|c|}{ Not employed } & 133 & 73.89 & 9828.00 & & \\
\hline \multirow{2}{*}{\multicolumn{2}{|c|}{ Problem-solving }} & \multicolumn{2}{|c|}{ Employed } & 25 & 111.22 & 2780.50 & & \\
\hline & & \multicolumn{2}{|c|}{ Not employed } & 133 & 73.54 & 9780.50 & & \\
\hline \multirow{2}{*}{\multicolumn{2}{|c|}{ Cognitive development }} & \multicolumn{2}{|c|}{ Employed } & 25 & 101.74 & 2543.50 & & \\
\hline & & \multicolumn{2}{|c|}{ Not employed } & 133 & 75.32 & 10017.50 & & \\
\hline \multirow{2}{*}{\multicolumn{2}{|c|}{ Organization and planning }} & \multicolumn{2}{|c|}{ Employed } & 25 & 103.66 & 2591.50 & & \\
\hline & & \multicolumn{2}{|c|}{ Not employed } & 133 & 74.96 & 9969.50 & & \\
\hline \multirow{2}{*}{\multicolumn{2}{|c|}{ Self-confidence }} & \multicolumn{2}{|c|}{ Employed } & 25 & 103.42 & 2585.50 & & \\
\hline & & \multicolumn{2}{|c|}{ Not employed } & 133 & 75.00 & 9975.50 & & \\
\hline \multirow{2}{*}{\multicolumn{2}{|c|}{ Diversity awareness }} & \multicolumn{2}{|c|}{ Employed } & 25 & 114.72 & 2868.00 & & \\
\hline & & \multicolumn{2}{|c|}{ Not employed } & 133 & 72.88 & 9693.00 & & \\
\hline \multirow{2}{*}{\multicolumn{2}{|c|}{ Technology }} & \multicolumn{2}{|c|}{ Employed } & 25 & 119.68 & 2992.00 & & \\
\hline & & \multicolumn{2}{|c|}{ Not employed } & 133 & 71.95 & 9569.00 & & \\
\hline \multicolumn{9}{|c|}{ Test Statistics $^{a}$} \\
\hline & 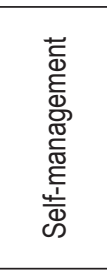 & 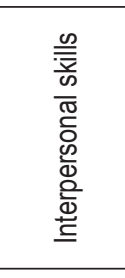 & 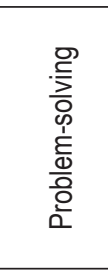 & 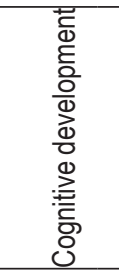 & 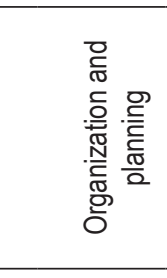 & 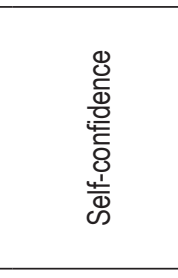 & 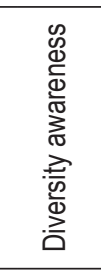 & 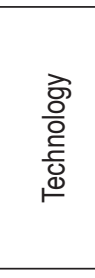 \\
\hline Mann-Whitney $U$ & 540.5 & 917.0 & 869.5 & 1106.5 & 1058.5 & 1064.5 & 782.0 & 658.0 \\
\hline Wilcoxon W & 9451.5 & 9828.0 & 9780.5 & 10017.5 & 9969.5 & 9975.5 & 9693.0 & 9569.0 \\
\hline Z & -5.377 & -3.573 & -3.802 & -2.679 & -2.905 & -2.881 & -4.287 & -4.811 \\
\hline $\begin{array}{l}\text { Asymp. Sig. } \\
\text { (2-tailed) }\end{array}$ & .0001 & .0001 & .0001 & .007 & .004 & .004 & .0001 & .0001 \\
\hline
\end{tabular}

Concerning the fifth question posed in the current research, significant differences were found ( $p=.0001$ ) between students involved in co-curricular activities and those categorized as involved, the latter demonstrating lower ranks on all the scales of the questionnaire (Table 8). 
Nadiia HORISHNA, Hanna SLOZANSKA, Olha SOROKA, Lyudmila ROMANOVSKA. Exploring the leadership skills of pre-service social work students: Implications for social work education

PROBLEMS

OF EDUCATION

IN THE $21^{\text {st }}$ CENTURY

Vol. 77, No. 5, 2019

Table 8. Summary of Mann-Whitney $U$-test for differences in leadership of social work students by involvement in co-curricular activities.

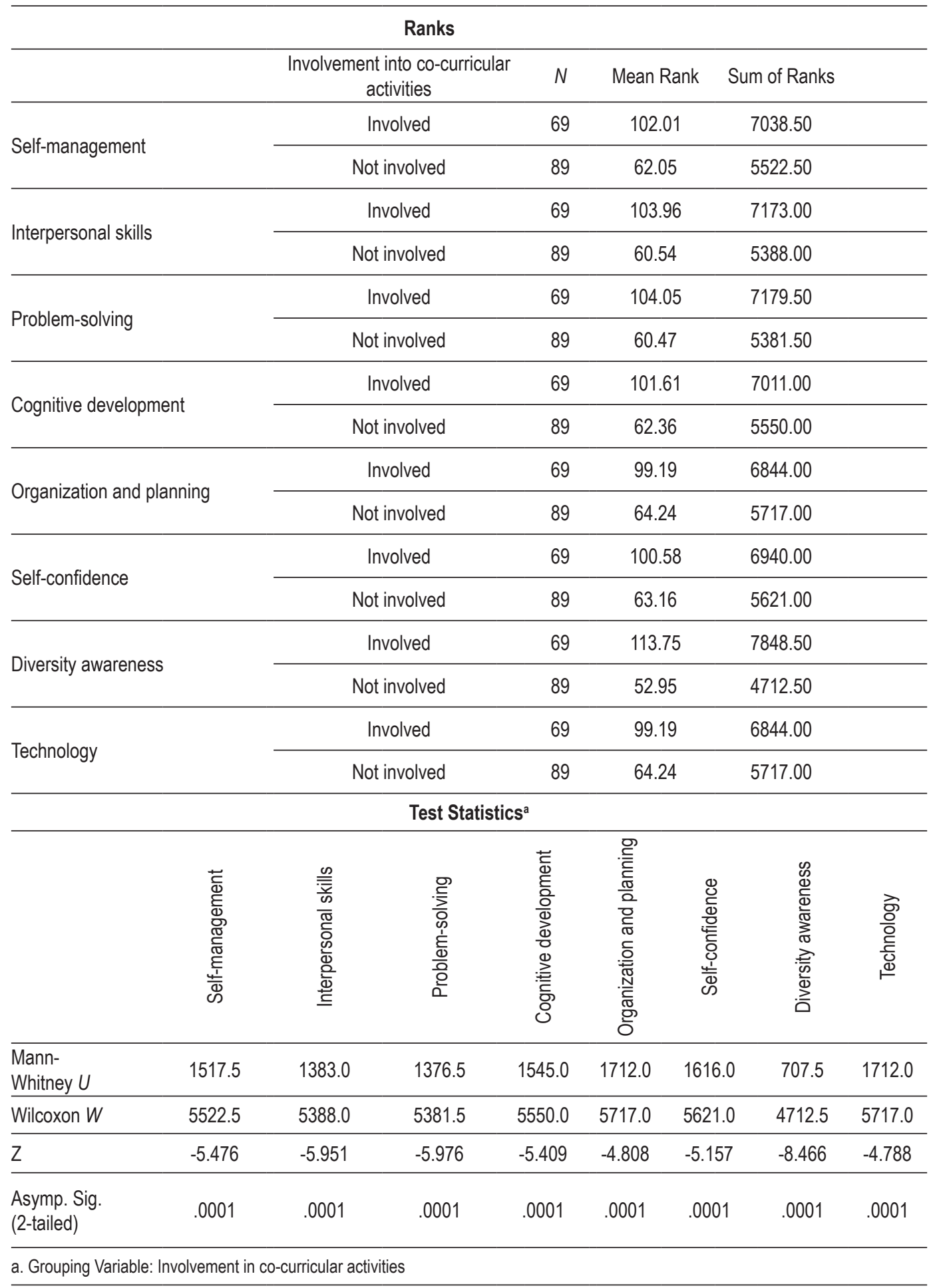


Nadiia HORISHNA, Hanna SLOZANSKA, Olha SOROKA, Lyudmila ROMANOVSKA. Exploring the leadership skills of pre-service social work students: Implications for social work education

PROBLEMS

OF EDUCATION

IN THE $21^{\text {st }}$ CENTURY Vol. 77, No. 5, 2019

610

\section{Discussion}

The purpose of this research was to find out what skills pre-service social work students had related to leadership and to determine if significant differences existed in terms of level and form of study, employment status and involvement in co-curricular activities. Students responded to each of the 60-ty items of the SLOI on a 5-point Likert scale with endpoints of poor (1) to excellent (5). The highest median scores were found for Interpersonal and Problemsolving scales. The lowest median scores were found for Diversity awareness and Selfconfidence scales. In general, the majority of responses to all the items fell below the midpoint of the scale, indicating lower than average levels of leadership skills.

The findings of the current study are consistent with the researchers' collective perception of the overall lack of leadership skills and preparedness of social workers to meet the challenges of the profession (e.g., Austin et al., 2011; Knee \& Folsom, 2012; Peters, 2017). No relevant studies focused on the intersection of either interpersonal or problem-solving skills and leadership outcomes to compare and discuss with the results of this research have been found, but both the theoretical literature and empirical research confirm that these two types of skills underpinning social work practice are well incorporated into the social work curriculum (e.g., Gockel \& Burton, 2014; Sheppard, \& Charles, 2017; Trevithick, Richards, Ruch, \& Moss, 2004). In contrast, a deficiency of diversity awareness in social work education was reported by several researchers (Bowie, 2003; Otelia Lee, 2010; Jani, Osteen, \& Shipe, 2016). In particular, Otelia Lee $(2010$, p. 262) recognizing the lack of diversity training, argued that social workers must be prepared to respond to the changing needs of a culturally diverse clientele. Despite the recognition of self-confidence as the fundamental basis from which leadership grows (Barrett, 2006), the cornerstone of leadership (Bartz, Bartz, \& Doctor, 2017), recent studies revealed a lack of its development in students what reduces the probability of trying difficult leadership tasks (Kouzes \& Posner, 2008) and impedes leadership development (Shinbrot, Wilkins, Gretzel, \& Bowser, 2019). So, students' low self-confidence might be one of the reasons for a generally low level of leadership skills.

The results also revealed significant differences in almost all categories of leadership skills by outcome variables for the study sample.

First, graduate students reached a significantly higher sum of ranks for each of the eight scales of leadership skills except for the Diversity awareness scale, where the difference was not deemed statistically significant. The question is whether such a difference is the result of random or some other unknown factors or aroused as a result of students' exposure to courses that (at least indirectly) foster leadership development. The research made by Iachini et al., (2015) examining the influence of program evaluation courses on students' leadership outcomes supports the latter assumption.

Secondly, full-time students demonstrated significantly higher levels of leadership skills on such scales as Cognitive development, Organization and planning, Self-confidence, Diversity awareness, and Technology. Though no research has been found to explore the relationship between the leadership development and form of study, it seems a logical explanation that fulltime education fosters the development of leadership skills due to its objective characteristics such as more in-depth training, active involvement in learning activities, interaction with faculty and other students, cooperation on course projects and work in a group, etc. The acquisition of leadership skills by part-time students, especially those not engaged in professional work, seems to be a challenge for social work educators. The absence or limited excess to developmental opportunities outside of the HEI's environment can significantly impede the development of leadership capacities.

Third, employed students scored significantly higher on all the eight scales of the questionnaire. It would seem that such results should contradict the findings set out in the 
previous paragraph. Since, usually, employed students prefer part-time study options, they socio-demographic data of students proved that the majority of employed students (72\%) had part-time jobs and combined them with full-time education. Thus, employment has a clear positive impact on the development of leadership capacities, especially in combination with full-time education. These findings are supported by a study of Salisbury, Pascarella, Padgett, and Blaich, (2012) who analyzed the data on 2,931 first-year American students to examine the effect of on- and off-campus employment on the leadership skill development. They have found out that in general, the impact of both was positive, with the latter being more significant even though extensive off-campus work simultaneously undercut the effect of co-curricular involvement on leadership.

Finally, a significantly higher level of leadership skills among students involved in cocurricular activities on all scales of the SLOI seems quite logical and consistent with findings of other studies (Foreman \& Retallick, 2013; Haber, 2011; Hall, Forrester, \& Borsz, 2008), revealing such positive outcomes of co-curricular participation for students' leadership capacities as development of attitudes, values, and aspirations, personal empowerment and growth, collaboration, educational development.

The results of this research should be accepted with caution as several limitations need to be considered. First, a convenience sample at three HEIs was employed, therefore, the results may not be sufficiently informative and generalized to the whole population of social work students. Second, other variables that can influence leadership skills, such as school experiences, academic performance, self-regulated learning, interpersonal relations, hobbies, and others were not controlled. Further, the findings of the current research are based on selfestimated leadership skills which allow for their inaccurate perceptions on respondents' part.

\section{Conclusions and Implications}

Improvement of leadership skills in bachelor's and master's programs in social work is essential as it has been found that these skills are not well developed at HEIs level in the current Ukrainian educational context. Recognizing the importance of all skills related to leadership, more attention should be paid to areas where the largest skill gaps have been found, such as diversity awareness and self-confidence.

One of the possible solutions to the gap in leadership skills of pre-service social work students is the implementation of a separate leadership course that would raise their awareness of leadership, identify and develop leadership skills. In our opinion, courses on leadership should be implemented both in the Bachelor's and Master's curriculum, their content reflecting the appropriate professional tasks, roles and responsibilities and ensuring continuity in the development of students' leadership capacities. Besides, informal leadership programs should be provided at the university level to provide opportunities for the development, refinement, and practicing those skills not only for social work students but for the entire campus. It is increasingly important considering that in none of the three universities the students have been exposed to such an experience during their professional education. Another potential solution to the deficiencies in the leadership skills is the creation of meaningful opportunities and the encouragement of students to participate in co-curricular activities such as soft skills training courses, projects within or beyond HEIs, volunteering, non-governmental organizations, additional internships, etc. Some of them might be recognized within the social work curriculum. The same applies to students employed by social service agencies. The research findings demonstrate that work experience is particularly strong in developing leadership skills, but there are always risks that unmotivated students wouldn't succeed academically. Thus, pertinent efforts to promote leadership development in part-time students, especially those unemployed, should be undertaken by faculty members and programs' administrators. 
Nadiia HORISHNA, Hanna SLOZANSKA, Olha SOROKA, Lyudmila ROMANOVSKA. Exploring the leadership skills of pre-service social work students: Implications for social work education

PROBLEMS

OF EDUCATION

IN THE $21^{\text {st }}$ CENTURY

Vol. 77, No. 5, 2019

612

The results of this research have several practical implications for leadership education in social work. They are a significant checkpoint to social work staff and administrators in the universities who participated in this research to reveal the level of students' leadership skills and to better understand the factors that influence their development. Its findings can also be used both to improve the effectiveness of leadership development efforts and to serve as a point of reference for other HEIs in the field of social work to follow.

Further research is required to better understand how leadership skills can be improved and honed through training, education and developmental experiences. The most important questions to be answered include: (1) What are students' and faculty perceptions of leadership in social work? (2) To what extent is leadership content integrated into the curriculum at different levels of social work education? (3) How do different types of curricular and co-curricular activities influence leadership development of social work students? (4) What are the specific challenges program administrators and faculty face in the implementation of leadership training and initiatives?

\section{Acknowledgements}

The authors would like to express their deep gratitude to Lilia Klos, Doctor of Sciences, Associate Professor of the Sociology and Social Work Department at Lviv Polytechnic National University for her help in data collection and assistance in testing the reliability of the Ukrainian version of the SLOI.

\section{References}

Austin, M. J., \& Ezell, M. (2004). Educating future social work administrators. Administration in Social Work, 28, 1-3. https://doi.org/10.1300/J147v28n01_01.

Austin, M. J., Regan, K., Samples, M. W., Schwartz, S. L., \& Carnochan, S. (2011). Building managerial and organizational capacity in nonprofit human service organizations through a leadership development program. Administration in Social Work, 35, 258-281. https://doi.org/10.1080/036 43107.2011.575339.

Barrett, D. A. (2006). Leadership perspective. Leadership Excellence, 23(4), 10.

Bartz, D. E., Bartz, D. T., \& Doctor, J. (2017). Confidence, vulnerability, and empathy: Friends to managers. International Journal of Business and Social Science, 8(10), 1-6.

Bento, A., \& Ribeiro, I. (2010). Sustainable leadership of senior students: The case study of Madeira. Journal of Teacher Education for Sustainability, 12(1), 66-74. https://doi.org/10.2478/ v10099-009-0047-9.

Bowie, S.L. (2003). Perceived diversity and multi-culturalism content in HBSE courses: An integrative methodological survey of African American MSW graduates from predominantly white institutions. Journal of Human Behavior in the Social Environment, 8, 1-23. https://doi. org/10.1300/J137v08n01_01.

Brilliant, E. L. (1986). Social work leadership: A missing ingredient? Social Work, 31, 325-331.

Call, C. R., Owens, L. W., \& Vincent, N. J. (2013). Leadership in social work education: Sustaining collaboration and mission. Advances in Social Work, 14(2), 594-612.https://doi.org/10.18060/3502.

Fajchuk, O. L. (2017). Ways to increase the motivation of students of the "social work" specialty for professional employment. Scientific works. Pedagogy, 291(279), 86-90.

Foreman, E. A., \& Retallick, M. S. (2013). Using involvement theory to examine the relationship between undergraduate participation in extracurricular activities and leadership development. Journal of Leadership Education, 12(2), 56. https://doi.org/10.12806/V12/I2/56.

Fronek, P., Fowler, J. L., \& Clark, J. (2011). Reflecting on reflection, leadership and social work: Social work students as developing leader. Advances in Social Work and Welfare Education, 13(1), 4970.

Globerman, J., White, J. J., Mullings, D., \& Davies, J. M. (2003). Thriving in program management environments: The case of social work in hospitals. Social Work in Health Care, 38(1), 1-18. 
Nadiia HORISHNA, Hanna SLOZANSKA, Olha SOROKA, Lyudmila ROMANOVSKA. Exploring the leadership skills of pre-service social work students: Implications for social work education

Gockel, A., \& Burton, D. L. (2014). An evaluation of prepracticum helping skills training for graduate social work students. Journal of Social Work Education, 50(1), 10-19. https://doi.org/10.1080/10 437797.2014.856234.

Grint, K. (2010). Wicked problems and clumsy solutions: The role of leadership. In S. Brookes \& K. Grint (Eds.), The new public leadership challenge, (pp. 169-186). Palgrave Macmillan. doi. org/10.1057/9780230277953_11.

Haber, P. (2011). Peer education in student leadership programs: Responding to co-curricular challenges. New Directions for Student Services, 133, 65-76.

Hall, S. L., Forrester, S., \& Borsz, M. (2008). A constructivist case study examining the leadership development of undergraduate students in campus recreational sports. Journal of College Student Development, 49(2), 125-140. https://doi.org/10.1353/csd.2008.0010.

Horishna, N., \& Slozanska, H. (2017). Dual degree programs in social work: Is it possible in Ukraine? Economics \& Sociology, 10(2), 165. doi: 10.14254/2071-789X.2017/10-2/12.

Iachini, A. L., Cross, T. P., \& Freedman, D. A. (2015). Leadership in social work education and the social change model of leadership. Social Work Education, 34(6), 650-665. https://doi.org/10.1080/026 15479.2015.1025738.

International Federation of Social Workers, (2014). Global definition of social work. Retrieved June 2, 2019, from https://www.ifsw.org/global-definition-of-social-work/.

Jani, J. S., Osteen, P., \& Shipe, S. (2016). Cultural competence and social work education: Moving toward assessment of practice behaviors. Journal of Social Work Education, 52(3), 311-324. https://doi.or $\mathrm{g} / 10.1080 / 10437797.2016 .1174634$.

Jones, B., Phillips, F. (2016). Social work and interprofessional education in health care: A call for continued leadership. Journal of Social Work Education, 52(1), 18-29. https://doi.org/10.1080/10 437797.2016.1112629.

Khmelnytskyi National University. (2015). Bachelor's degree program in Social Work. Retrieved from http://www.onl.org.jp/horo 3/html.

Khmelnytskyi National University. (2018). Master's degree program in Social Work. Retrieved from http://www.onl.org.jp/horo 3/html.

Kirst-Ashman, K. K. (2000). Human behavior, communities, organizations, and groups in the macro social environment: An empowerment approach. Australia: Belmont, Ca: Wadsworth Pub.

Knee, R. T., \& Folsom, J. (2012). Bridging the crevasse between direct practice social work and management by increasing the transferability of core skills. Administration in Social Work, 36, 390-408. https://doi.org/10.1080/ 03643107.2011.604402.

Kouzes, J. M., \& Posner, B. Z. (2008). The leadership challenge. New York, NY: Doubleday Currency.

Lawler, J. (2005). Leadership in social work: A case of caveat emptor? British Journal of Social Work, 37(1), 123-141. https://doi.org/10.1093/bjsw/bch404.

Lviv Polytechnic National University. (2015). Bachelor's degree program in Social Work. Retrieved from http://lp.edu.ua/education/majors/IHSS/6.130102/8/2015/ua/full.

Lviv Polytechnic National University. (2018). Master's degree program in Social Work. Retrieved from http://lp.edu.ua/education/majors/IHSS/8.231.00.01/19/2018/ua/full.

McDonald, C., \& Chenoweth, L. (2009). Leadership: A crucial ingredient in unstable times. Social Work \& Society, 7(1), 102-112.

Menefee, D. (1997). Strategic administration of nonprofit human service organizations: A model for executive success in turbulent times. Administration in Social Work, 21(2), 1-19. https://doi. org/10.1300/J147v21n02_01.

Nandan, M., London, M., \& Bent-Goodley, T. (2015). Social workers as social change agents: Social innovation, social intrapreneurship, and social entrepreneurship. Human Service Organizations: Management, Leadership \& Governance, 39(1), 38-56. https://doi.org/10.1080/23303131.2014. 955236.

Othelia Lee, E. K. (2010). More than a mission statement: Implementing diversity and social justice initiatives within a school of social work. Multicultural Education \& Technology Journal, 4(4), 261-271. https://doi.org/10.1108/17504971011087559.

Overocker, E. G. (2013). Removing the exclusivity of leadership: An evaluation of first-year students' perceptions of their skills (Doctoral dissertation, University of Oklahoma). Retrieved from https:// shareok.org/handle/11244/6071. 
Nadiia HORISHNA, Hanna SLOZANSKA, Olha SOROKA, Lyudmila ROMANOVSKA. Exploring the leadership skills of pre-service social work students: Implications for social work education

PROBLEMS

OF EDUCATION

IN THE $21^{\text {st }}$ CENTURY Vol. 77, No. 5, 2019

614

Peters, S. C. (2017). Social work leadership: An analysis of historical and contemporary challenges. Human Service Organizations: Management, Leadership \& Governance, 41(4), 336-345. https://doi.org/ 10.1080/23303131.2017.1302375.

Pivoriene, J., \& Bardauskiene, R. (2016). Social work with families at social risk promoting gender equality. SHS Web of Conferences, 30, 00024. https://doi.org/10.1051/shsconf/20163000024.

Randle, E.N.(2016). Social work leadership: Emotional intelligence in a rural BSW program. Contemporary Rural Social Work Journal, 8(2), 77-85.

Rank, M. G., Hutchison, W. S. (2000). An analysis of leadership within the social work profession. Journal of Social Work Education, 36(3), 487-502. https://doi.org/10.1080/10437797.2000.107 79024

Rosenberg, G., \& Weissman, A. (1995). Preliminary thoughts on sustaining central social work departments. Social Work in Health Care, 20(4), 111-116. https://doi.org/10.1300/j010v20n04_08.

Salisbury, M. H. \& Pascarella, E. T. \& Padgett, R. D. \& Blaich, C. (2012). The effects of work on leadership development among first-year college students. Journal of College Student Development, 53(2), 300-324. https://doi.org/10.1353/csd.2012.0021.

Sheppard, M., \& Charles, M. (2017). A longitudinal comparative study of the impact of the experience of social work education on interpersonal and critical thinking capabilities. Social Work Education, 36(7), 745-757. https://doi.org/10.1080/02615479.2017.1355968.

Shinbrot, X. A., Wilkins, K., Gretzel, U., \& Bowser, G. (2019). Unlocking women's sustainability leadership potential: Perceptions of contributions and challenges for women in sustainable development. World Development, 119, 120-132. https://doi.org/10.1016/j.worlddev.2019.03.009.

Skidmore, R. (1990). Social work administration: Dynamic management and human relationships. Englewood Cliffs, NJ: Prentice-Hall.

Slozanska, H. I. (2017). Legislative support of the work of a social worker in a territorial community. Research in the Third Millennium: Social, Legal, Economic and Humanitarian Dimensions. Proceedings of the Second International Scientific and Practical Conference, 2, 293-296.

Ternopil V. Hnatiuk National Pedagogical University (2015). Bachelor's degree program in Social Work. Retrieved September 12, 2018, from http://tnpu.edu.ua/about/public_inform $/ 231 \% 20$ Sotsialna\%20robota\%20-\%20bakalavr.pdf.

Ternopil V. Hnatiuk National Pedagogical University (2018). Master's degree program in Social Work. Retrieved September 12, 2018, from http://tnpu.edu.ua/about/public_inform/231\%20 Sotsialna\%20robota\%20-\%20magister.pdf.

Thompson, J., Menefee, D., \& Marley, M. (1999). A comparative analysis of social workers' macro practice activities. Journal of Social Work Education, 35(1), 115-124. https://doi.org/10.1080/10 437797.1999.10778951.

Trevithick, P., Richards, S., Ruch, G., \& Moss, B. (2004). Teaching and learning communication skills in social work education. London: Social Care Institute for Excellence.

Vann, M. (2000). Student leadership outcomes inventory. University Unions and Student Activities, Virginia Polytechnic Institute and State University, Blacksburg.

Vasylenko, O. (2016). Guidelines for graduates of secondary schools for choosing a future profession in modern conditions. Collection of Scientific Papers of the National Academy of State Border Guard Service of Ukraine. Series: Pedagogical Sciences, 3, 61-71.

Videka-Sherman, L. Allen-Meares, P1, Yegidis, B., \& Yu, Y. (1995). Social work deans in the 1990s: Survey findings. In F. Raymond (Ed.), The administration of social work education programs: The role of deans and directors (pp. 1-23). Columbia, SC: National Association of Deans and Directors of Schools of Social Work. Washington, DC: NASW Press.

Zherobkina, T., Kudelya, M., Samohin, I., Stadnij, Ye., \& Kogut, I. (2016). Socio-economic portrait of students: Survey results. Retrieved from https://cedos.org.ua/uk/articles/sotsialno-ekonomichnyiportret-studentiv-rezultaty-opytuvannia. 
Nadiia HORISHNA, Hanna SLOZANSKA, Olha SOROKA, Lyudmila ROMANOVSKA. Exploring the leadership skills of pre-service social work students: Implications for social work education

Received: August 22, 2019

Accepted: October 02, 2019

PROBLEMS

OF EDUCATION

IN THE $21^{\text {st }}$ CENTURY

Vol. 77, No. 5, 2019

615

\begin{tabular}{|ll} 
Nadiia Horishna & PhD, Associate Professor, Ternopil Volodymyr Hnatyuk National Pedagogical \\
& University, L. Kurbas str. 6/274, Ternopil, 46016, Ukraine. \\
& E-mail: nadiahorishna@yahoo.com \\
& Website: https://www.researchgate.net/profile/Nadia_Horishna \\
& ORCID: 0000-0002-9724-7098. \\
\hline Hanna Slozanska & Doctor of Sciences, Associate Professor, Ternopil Volodymyr Hnatyuk National \\
& Pedagogical University, 2, Maxyma Kryvonosa str., Ternopil, 460027, Ukraine. \\
& E-mail: kulynyak@elr.tnpu.edu.ua \\
& Website: https://www.researchgate.net/profile/Hanna_Slozanska \\
& ORCID: 0000-0002-8394-4925. \\
\hline Olga Soroka & Doctor of Sciences, Professor, Ternopil Volodymyr Hnatyuk National Pedagogical \\
& University, 2, Maxyma Kryvonosa str., Ternopil, 460027, Ukraine. \\
& E-mail: sorokaolga175@gmail.com \\
& Website:https://scholar.google.com.ua/citations?user=twWrF7sAAAA\&hl=uk \\
& ORCID: 0000-0003-1483-8974. \\
\hline Lyudmila Romanovska & Doktor of Sciences, Professor, Khmelnitsky National University, 1, Instytuts'ka \\
str., Khmelnytskyi, 29016, Ukraine. \\
E-mail: Iroman@online.ua \\
Website:https://scholar.google.com.ua/citations?hl=ru\&user=qWhbVD4AAAJ \\
ORCIDiD: 0000-0001-7547-4575.
\end{tabular}

